\title{
Ethics of Knowledge Sharing: A Perspective of Social Ontology
}

Ranjan K. Panda (IIT Bombay, India)

\section{Knowledge as Ability: An Appraisal of Personal Ontology}

In a societal framework knowledge is regarded as a complex phenomenon refers to opinion, data, information, idea, understanding, skill, mystic insight, wisdom, etc. The complexity is part of theorization of knowledge, which lies in the properties of experience, reason, emotion, and intuition, etc. Knowledge can be experiential, rational and intuitive. Experiential and rational knowledge is believed and justified, whereas the intuitive knowledge is mostly taken as certain and infallible. Nevertheless, both experiential and intuitive knowledge are based on consciousness. The knower as conscious being has the ability to acquire, articulate and actualize the content of knowledge (Hyman 1999, 436439).

The power of is actualizing is grounded in the intentionality of consciousness. Intentionality forms the structure of knowledge by relating the knower with the object of knowledge. In other words, in the form of intentional representation the content of experience is known and further articulated for communication. The act of representation and the act of communication are two functional aspects of human intentionality (Searle 1983). Knowledge sharing involves communication in which the content of knowledge is transferred to the learner. In this context, it is presumed that the learner would be minimally able to comprehend the content which is being communicated. Thus, knowledge sharing presupposes apart from biological and psychological 
abilities, a cultural background in which we exchange ideas, share information, etc. (Searle 1983, 144-159) The cultural background acts as a normative condition for regulating the act of sharing. Without this normative pre condition of sharing knowledge would lose its integrity. Let's illustrate it with an example from the Mahabharata, one of the great Indian epics.

In the Mahabharata, when Dronāchārya, the teacher of Pāndavas and Kauravas, intends to test the archery ability of all his disciples, he takes all of them near a tree and instructs that there is a bird sitting in one of the branches of the tree. He then asks all his disciples to fix the target for shooting the bird. Following the teacher's instruction they made efforts in targeting the bird. In the meanwhile, Dronāchārya keeps asking the disciples one by one, whether they are able to set their respective targets. Responding to Dronāchārya, one of them says he is not able to see the bird but he can shoot the bird by shooting the branches of the tree. Another disciple replies saying that he is able to see the leaves only. Someone else replies that he is able to target the bird. But when it is asked to Arjun, he replies saying that 'he is able to target the bird's eye.' Arjun's reply is considered to be the best amongst all the replies, for Dronāchārya. It is not because Dronāchārya was hoping for such specific answer, but he knew that targeting the eye of the bird is better for shooting the bird. Before shooting it is advantageous to know the attention of the bird and that becomes clear by observing the eyes of the bird. Though Dronāchārya's all these disciples had the ability to shoot the bird by shooting the branches, leaves and the tree, still it was important for Dronāchārya to know their respective abilities; precisely the modes of actualizing the knowledge. As the contents of actualization of these disciples differ their corresponding abilities also differ. This signifies that the ability is something unique and personal. Hence, it is important to discuss whether knowledge as personal ability can be shared at all.

Traditionally, it is believed that all the material possessions and properties can be shared physically and legally. Knowledge as intellectual property is exclusively in the possession of the knower which cannot be physically divided and shared. This personification of knowledge is illustrated by Vishnu Sharma:

Jñātibhi bantyatě naiba, chorenāpi naniyate, Dānena naksyamjāti, Vidyā ratanam mahādhanam (Acharya 1952, 28). 
This sloka signifies knowledge that results of vidya (education/ learning) is the most valuable wealth, is physically non-sharable amongst the kith and kin. And the feature of immateriality of knowledge suggests that it cannot be stolen by others. Moreover, it entails that knowledge per se is one of the valuable resources if offered to educate someone then there is no loss of knowledge. Rather knower is enriched in such mode of communication (Schmitz 1994, 768).

The notion of exclusive ownership of knowledge entails personal ontology. Knowledge is person centric, in the sense that the content of knowledge is articulated by the knower. And the knower knows how to actualize his ability. The ability and mode of actualization conforms the knower's ability and authority to use knowledge. In this regard, the knower's decision is a voluntary act. All voluntary actions are subject moral appraisal and therefore must be guided by norms; otherwise it may have negative impacts. For example, Dronāchārya's disapproval of sabara Ekalavya's interest of leaning warfare along with the Kauravas and Pāndavas is not morally justified. Being a sabara (a tribal person), he was not fulfilling the criteria of admission in his āshrama - the place of learning and had no right to learn along with the princes. This shows the denial of right to knowledge (Sen 1987 \& Audi 2005). Right to know is person's moral right exercised with self-interest. A person is free and must be self-motivated for expressing his will to learn. Dronāchārya's rejection is an indication of voluntary act of knowledge sharing. The intention of sharing here denies 'the intrinsic value attached to the existence or fulfillment of rights.' (Sen 1987, 49-50). It lacks proper moral grounding as Dronāchārya shows his individualistic concern and selfish motive while demanding Ekalavya's right-hand thumb for gurudakshinā tradition of repaying the teacher after formal education. Dronāchārya's acknowledgement and acceptance of gurudakshina is not only an instance of violation of moral rights but also is a sign of dissolution of normativity in the field of knowledge sharing.

To avoid such problems, we argue that the right to share the knowledge demands a normative usage with a good reason. Knowledge should be meaningfully articulated taking into consideration of systematic formation, examination, and practice. A non-normative framework might not help to prevent misutilization of knowledge. However, knowledge cannot just remain within the domain of the subject or the knower. Knowledge ought to be shared for the sake of its own development, so that if the need arises it can be recalled at any point in time. In this connection, knowledge development has pragmatic concern and the user of knowledge must examine the practical as well as 
theoretical utility. The practical utility of knowledge is realized only when we apply knowledge to resolve certain practical difficulties. For instance, knowledge of technology helps in solving certain practical difficulties. On the other hand, the theoretical utility of knowledge refers to the internal growth and novelty of knowledge.

\section{Human Intentionality as an Ontological Ground of Knowledge}

Knowledge development is essential to human life. It shows the ways of surviving, adopting to new situations, competing with others, establishing harmony, etc. These features of knowledge building are rooted in the intentionality of the being. A biological being would have some intentionality through which it interacts with the world. So far as the human intentionality is concerned it is intrinsic to the mind. The notion of intrinsic intentionality not only explains the intentional interaction with the world but also explicates the self-conscious activities. The self-consciousness unfolds the dual function of intentionality: firstly, humans act with a psychological mode that results in bringing condition of satisfaction, and secondly, it shows the direction of fit. (Searle 1983, 172) So far as the latter is concerned intentionality works in two ways; that is, relating the self with the world and the world with the self. It is precisely in this intentional mode of interaction, the human agency has shown the ability to comprehend, rationalize, evaluate, etc. The former, on the other hand, is the consequence of the latter. The satisfaction and happiness that an agent obtains shows the fulfillment of the psychological mode in which the act is being performed. Thus, the intentionality of the self illustrates its own modes of action as well as relates to the action of the other.

Human intentionality is not merely biological, but also has the mental and the social features. The functional mode of intentional activities, according to Searle, would show the relationship between the biological and the social vis-à-vis the mental. In other words, every intentional action performed by the individual is conditioned by the biological and the social background (Searle 1983, 141-159) He explains this by drawing out attention to the notions of knowing how and knowing that. For instance, if the chair-person during a seminar says that "the paper is open for discussion," the chairperson expects that discussion, deliberation, questioning and answering would proceed according to the academic convention. There is a presupposition of convention - academic culture in which these activities take place. And it is expected that the chairperson and others whoever participates in the seminar would know 
about the normativity of the convention. The chairperson's knowledge about conducting the proceeding explains the ground of knowing-how which lies in the social or cultural background of academic activities like dialogue, discussion, debate, criticism, etc. in the seminars and conferences. Knowing how illustrates the way the person has acquired the skill or expertise. Moreover, the very act of uttering statement, making a remark, using gesture, etc. is physical activities that refer to the biological background. Thus, knowledge acquisition, in Searle's theorization of intentionality can be explained with reference to the biological and the cultural backgrounds.

However, the biological and the cultural backgrounds are connected by the intentionality. Illustrating the relationship between background and intentionality, Searle writes,

[it] occurs in a coordinated flow of action and perception, and the Background is a condition of possibility of forms taken by the flow. The flow of intentionality tends to rise to the level of the Background ability it reaches all the way down to the bottom of ability (Searle 1992, 195).

Thus, Searle treats intentionality as a persisting feature intrinsic to both conscious mental life or thought experiences and the background. It is because one always intends to act, or have desired to share his/ her ideas or thoughts, and in the process he gets satisfaction. Intentionality persists in the very process of realizing the conditions.

Moreover, as a connecting principle the intentionality relates to the conscious and the unconscious background capacities (Searle 1994 \& Panda 1997). Since intentionality persists in the function of thinking that helps in developing skill and stance. In other words, through practices different skill can be developed; depending on the intentionality of individual's interest and ability. And this form of intentionality rises from the bottom of conscious experiences to reach at the background level. On the other hand, the same background or the developed skill helps in representing thoughts or implementing ideas. For instance, when a skier practices he follows all the rules and instructions of his coach. If the skier has intended to learn and win the race, then from one level of his learning he tries to reach out to a level of perfection. And while obtaining that skill he not only applies those rules but also invents new ways of doing it. The intention of articulating of certain techniques and applying them during the race is something significant. It shows that intentionality is present in both the cases, i.e., for developing the 
skill as well as for applying it. Thus, intentionality is instrumental in knowledge creation.

Knowledge building is necessary for developing social and cultural life. Human beings do live a cultural life. The cultural aspect plays an important role in making human life significant. That is to say, many of the natural behaviours are being regulated and refined through the cultural activities and norms. The practice of cultural activities and follow up of norms in society do influence action. These actions are regulated by the norms for the realization of values. The cultural life is value laden. Searle writes,

Humans are distinct from other animals in that they have a capacity to create not merely a social but an institutional reality. This institutional reality is, above all, a system of deontic powers. These deontic powers provide human agents with fundamental key for organized human society: the capacity to create and act on desired - independent reasons for action (Searle 2007, 125).

Animals do exhibit natural behaviour which may be guided by desires and instincts or natural characteristics. Only humans try to control their natural instincts and regulate their actions in the direction where actions are justified by reasons, emotions, and virtues. Human actions are not just rational but also normative. The deontic power refers to the normative ability of judging the content of thoughts and action. This is something significant of the human beings engaged in knowledge creation. This ability pertains to all kinds of knowledge such as scientific, cultural, religious, moral, etc. - It is the power to evaluate the very content of knowledge per se. The ability to exercise the power of judging the right and wrong; the will to perform certain duties; desire to show empathy, aspiration to know the truth, etc., unfold an important mode of the function of human intentionality at the social level.

Furthermore, at the social level, intentionality works in two modes. They are, the constitutive intentionality and the regulative intentionality (Searle 1970, 30). Norms and institutions are based on constitutive intentionality, whereas the function of institutions is governed by the regulative intentionality. Nevertheless, these institutions also regulate our actions through imposing certain rules on us, which show the function of regulative intentionality. They are not two different kinds of intentionality; rather they exhibit two different modes of functions. Intentionality, therefore, not only constitutes the rules but also defines the rules.

Thus, human civilization flourishes not only creating institutional facts but also creating norms and rules that regulate institutions and maintain 
values. In this regard, the intentionality of knowledge creation is not therefore merely confined to survival but also to the values defining the meaningful existence of beings. Meaningful existence can be stated with regard to the development of personal well-being as well as the development of social well being. Unless one intends to relate to these two aspects of the being, i.e. the personal and the social, one may fail to find the novelty of life vis-à-vis the novelty of knowledge.

\section{The Economics of Knowledge Development}

Knowledge sharing as one of the essential means for development has larger significance. It includes the marker of personal and social well-being (Sen 1987, 73) These two are often not considered to be related. A person can comprehend one's well-being without taking into account the well-being of the other. They do represent two ontological pools. Nevertheless, they share an intentional relationship between them which is synchronic as well as diachronic. In a communicative framework they share a same normative ground, hence the relationship is synchronic. The individual or the self realizes its own being while participating with the other. And such participation is a part of an intentional field which is irreducible to any single individual's subjective intentionality. On the other hand, the individual intentionality as primordial feature of conceiving the social, works in the mode of diachronic relationship with the other. However, we need not look at them as parallel events while contemplating on the notion of development, but they are to be intentionally linked to comprehend the collective vision by walking and working together (Toumela 1991) towards the realization of common social values by creating and restoring the public goods.

The development of public goods requires resources. Creation and utilization of the resources are matter of economic and moral concerns. Economists have emphasized the optimal utilization of material resources and of late considered the significance of intellectual resources. Knowledge as an intellectual resource generates wealth creating opportunities of income and investment. It renews its content in the course of development indicating the renewal of intellectual resource. Hence, it is the driving force of the whole process of development. As Schumacher writes,

All history - as well as current experience - points to the fact that it is man, not nature, who provides the primary resource: that the key factor of all economic 
development come out of the mind of man. Suddenly there is an outburst of daring, initiative, invention, constructive activity, not in one field alone, but in many fields all at once. No-one may be able to say where it came from in the first place; but we can see how it maintains and even strengthens itself: through various kinds of schools, in other words, through education. In a very real sense, therefore, we can say that education is most vital for all resources (Schumacher 1993, 60).

Education as an important means of knowledge creation requires not only the knowledge seeking individuals but also the proper environment for the cultivation knowledge. In this regard, there is a need to integrate the economic concern with the basic moral concern. The lack of moral concern for the public educational institutions in India as centers of learning has failed because of the degeneration of the normative standards. As a result, it has affected not only the academic productivity but also has failed to attract first-rate scholars to academics. Therefore, there is a basic need to develop educational institutions with a motive of renewing the academic culture.

The degraded practice of academic culture will not only affect negatively the process of knowledge sharing but also demean the value of knowledge in society. Hence, ethics of knowledge sharing appeals to develop a common will for the protection of ethos of educational institutions. Such renewal will ignite hope of creating new ideas. Hence, it is necessary to inculcate academic values before renewing the educational system in India. The renewal must have a proper normative grounding to integrate the values of education with quality of life. If social development emphasizes to have quality life then it should be part of our thinking. And that would come through education which has the potency to transform the pattern and style of thinking and living. Education as the breeding ground of quality life must show the path of meaningful integration of knowledge with the life. Thus, there is a need for emphasizing rational and critical thinking as a form of life in order to strengthen the normative aspect of knowledge sharing vis-à-vis the normativity of social development.

It is observed that knowledge is no more people centered; rather it is becoming technology centered. The use of technology is so much in the social spheres of life; it has endangered the personal aspect of reality. Knowledge in this sphere is detached from the subjectivity of the knower. This detachment is slightly delicate because articulation at various levels making knowledge passes through many channels before it is implemented. This shift of knowledge from the personal to the social shows the change in the ontology of knowledge. Knowledge as property in the market loses its personal belongingness and gains its social status. This as status marker opens up a new 
horizon where knowledge acquires the property being sharable. Sharing necessitates normative condition: it demands much care and supervision in order to be kept in the custody of the other. And, the other is then empowered as trustee of knowledge. Thus, in the domain of the social the ownership of knowledge changes that shows the ways to social ontology.

Moreover, knowledge economy is regulated by the market. In the market dominated society the process of introducing knowledge to the social world is technical and systematic. This process of knowledge creation is not only application oriented but also makes the content explicit. Scientific thinking cultivated from the point of view of application is basically converted knowledge-content in the form of a market-product. The product operates in a proper regulative structure. Patents, copy rights and intellectual property rights are introduced for the normative regulation of knowledge in the market.

The knowledge processed in a competitive market atmosphere needs constant evaluation and renewal. Unless the value of the product is assessed and created according to the demands of the market situation there is no guarantee that such product would survive for long. Hence, there is a consistent demand of production of new knowledge and its faster dissemination. In this regard, market systematically directs knowledge through brochures, symbols, advertisement for effective communication.

Thus in the market centered economy, knowledge production is influenced by the market. The curriculum of the institutions is structured to meet the demand of the market. Since many high standard professionals are needed to maintain the process, we only produce intellectuals who would fit into the system to provide better service and in return there is huge material gain. Knowledge sharing thus becomes largely money oriented and aims at material development. In other words, the market and the capital create knowledge system and produce the kind of knowledge it requires to maintain the growth of economy.

\section{Knowledge Sharing: the Trade between Private and Public Sphere}

We need to examine the normative intentionality of knowledge sharing inclined towards the market economy. Firms and companies do not share their knowledge which is unique to them. For instance, documentation, work routine, trade secrets, etc. have still remained private (Matusik 2002, 458). Sharing the private knowledge among all the members belonging to a company is also restricted. Nevertheless, the intentional transfer of data or 
information within the system requires a formal integration mechanism. This indicates a normative relationship within the cross functional teams, interdepartmental coordination, etc. Privacy is needed to prevent misuse and distortion of data.

However, company and institutions as primary stock-holders of data are often reluctant to share with secondary investigators. They emphasize that sharing is a voluntary activity and not an obligation (Stanley \& Stanley 1998). Sharing as a voluntary action empowers the stake-holder of data by imposing certain normative condition on the secondary researchers. Organization as an agent acts voluntarily with certain discretionary power that helps them in exercising the right to permit or rationalize of the refusal. Moreover, as owners of data, organizations are quite imposing of certain standards on secondary researchers. A fair sharing must fulfill the desirability conditions laid down by the standards for the evaluation of integrity and trust of the secondary researcher. The onus is on the secondary researcher that they must live up to the normative standard imposed on them. Secondary researchers are often treated as less qualified agents for analyzing and interpreting the data. Nevertheless, the mode of sharing remains partial (Spencer 2000). Companies and corporate always serve their own interests, and do not feel obliged to share the data. Hence sharing information or data remains a voluntary act for them.

Sharing, as an obligation amounts to grant rights and duties to the agency as the custodian or trustee of knowledge. Sharing is a collective enterprise must maintain a normative bond between individuals to realize collective goal. Hence, both primary stock-holders and the secondary researchers must be accountable for any kind of irregularities and misuse of knowledge. Moreover, in some cases sharing is not obligatory action, for instance, it is not encouraged within certain field of scientific research and strategic security matters. In these fields one cannot be open to an altruistic model where every researcher and investigators are entitled to reach out or share research data freely. Free sharing and open access to information would make it idealistic and simple (Stanley \& Stanley 1998, 175). However, in the other cases, like developmental research, the growth of knowledge depends on data sharing; hence it is warranted that there should be 'balance between data sharing and the development of the original data sets.' (Stanley \& Stanley 1998, 197).

Moreover, the development of private knowledge and its efficiency are benefited profoundly by the availability of public knowledge. Firms and organizations though maintain privacy they keep themselves engaged with the 
outer-world through their networks, alliances and local proximity. In the public domain knowledge is open and there is no competition and priority involved in accessing to public knowledge. Cultural knowledge falls in this category of public knowledge. It is also known as tacit knowledge. Knowledge articulated in this realm sometimes works more effectively than the knowledge articulated in the realm of academics and other institutions. Though the process of articulation in the academia is scientific and explicit, still no guarantee is there that it would be efficient to produce desired consequences. For instance, some sociologists, social activists and environmentalists failed to stop the fishermen of Gujarat cost from hunting the whales. But this violent act of the fishermen was stopped when Murari Bapu talked to these fishermen mentioning that the whales belong to their ancestors. Shiv Visvanathan illustrates this idea showing the failure of scientific knowledge and success of the knowledge articulated by religious gurus. The gurus of the globalized world are effective whereas scientific knowledge is ineffective sometimes. These gurus communicate the ideas in the language of occult which Visvanathan calls occult sociology (Visvanthan 2006).

At the outer-world cultural knowledge is mostly available in tacit form. The tacit knowledge is considered implicit in its nature; still it requires rational articulation and deserves mass communication for the benefit of the humanity. For instance, Buddha, Gandhi, Baba Ramdev, all have contributed significantly to different aspects of culture such as social ethics for harmony and peace, nonviolence as means for political reformation and yoga as health care system, respectively. The knowledge is shared without any intention to make profit. However, sharing the cultural knowledge is personal and deeply rooted in individual's feeling and experience. The individual develops his understanding, personal beliefs and insights reflecting on the tradition and the content of cultural knowledge.

\section{Knowledge Sharing as an Obligatory Action: Locating its Ontology}

All knowledge, economical, scientific, medical, political, etc., are grounded in certain norms for generating right kind of knowledge. For instance, in the case of market economy, it is not just making ample profits but market also intends to process the profit to all sectors of society. There are normative presuppositions through which it tries to realize its end. As Werkmeister (1967) emphasizes, 


\begin{abstract}
A market economy is possible in the long run only if honesty, self-discipline, justice, respect for human dignity, public spirit, and similar virtue prevail. These virtues are not product of the market - of supply or demand and of free competition; they are, rather, presuppositions, their moral framework, and rooted in social commitments which transcend the market as such. It is not the market that creates our values. It is our valuation that creates market and sustains the market. (cf., 218-219).
\end{abstract}

Market functions on the background of certain moral forces. These moral forces are intentionally structured to restore certain basic human values. Unless we show the minimum commitment and societal concern for the other, market economy cannot sustain and produce the growth of economy. The very concern for such practice of economy is significantly drawn upon a normative framework of knowledge sharing.

Knowledge sharing as an obligatory action involves the knower and the learner in that normative framework in which they share a common intention (Bratman 1999, 95) upholding mutual reciprocity and cooperation. That makes sharing a collective enterprise for knowing. In the case of natural science and social science, research is a collectively performed. A few student-researchers who pursue their work under someone's supervision are the learners, whereas the supervisors themselves are called primary researchers. Unless the primary researcher shows any obligation for the secondary researchers, knowledge sharing will be vulnerable. Hence, it is obligatory that owner of the knowledge must care for the other and treat the sharer as an end but not as a means (Kant 1964, 101). If the former uses the latter as means to gain power there is no loss of moral dignity. Knowledge as power has the potency for intentional misutilization, whereas knowledge as virtue creates harmony (Chattopadhyaya 1991). Knowledge as virtue makes a person competent at the same time morally committed to learn from the other. Thus the knower not only restores the dignity of the learner, but also gives an opportunity to the learner to exercise his moral rights - right to knowledge.

Caring as a normative value signifies the intellectual virtue of the knower. The knower must have the intellectual ability of relating as well as distancing oneself from the things that we must care for. Showing the significance of this virtue - care-knowing, Dalmiya (2002) writes,

The root notion of caring for a person generates an epistemic vigilance not only about the direct object of care but also the nature of motivation of the caring." (cf., 35). 
One must self examine the motivation of initiating an action as well as pursing it. Caring is not one-sided activity, rather it requires mutual reciprocity. And hence care-reception is essential feature of sharing. This according to Dalmiya (2002) creates "an avenue to register the wishes, and even possible disapproval, of the cared for. It thereby makes the cared for an active participant in sustaining caring." (cf., 38). Caring needs to be sustained for making the participants morally committed and responsible. The attitude of mentoring performed by the primary researcher is significant in this regard. His involvement in the entire process of investigation and learning shows his moral concern towards his fellow researcher or students. Here, 'caring begins in an ethical moment' of a researcher's academic life initiating a moral commitment and at the same time cultivating 'critical engagement with the commitment' that gives birth to epistemic responsibility. In other words, knowledge development as an epistemic responsibility should be integrated with moral responsibility (Dalmiya, cf., 49). Knowledge sharing needs both of them in order to show that caring is an integral part of all kinds of epistemic enterprises. The virtue of the enterprise lies in developing trust and good will which helps in maintaining reliability and responsibility in the field of sharing.

Furthermore, caring does indicate the act of valuing. Explaining the difference between value and valuing, Audi (2007) points out that value signifies something worthy, valuing signifies caring. He writes,

\footnotetext{
mixing these up is abetted by how commonly we care about is intrinsically valuable and hence has non-instrumental worth - value even apart from any good effects. Valuing the valuable is fitting; but, as vanity and hunger for power show, people sometimes care about things that are neither good in themselves nor lead to anything that is. Valuing is not always directed toward the valuable (cf., 36-38).
}

Hence the intention of valuing and caring evaluated because knowledge developed, accumulated and used for gaining power and material prosperity may remain guided by the psychological satisfaction and economic gain. It is obvious that market-economy would generate this kind of reality which is apparently motivated for making profits. And that may invite any kind of reason for justifying the rights of knowledge sharing. To put any kind of reason for justifying the profit motives and making an action effective is not normative at all. Rather, in the realm of knowledge economy sharing knowledge as normative act should be grounded in good reason (Dancy 2000). It is because 'good is beyond the satisfaction of personal desire' (Dalmiya 2002, 42-43) and hence mere rational justification for an action needs to be examined for the development of knowledge. If the 'motivating intention of action is not good 
then it is not be considered as a reason at all.' (Dancy 2000, 3). The construal of the content of motivation, thus, ought to be guided by reason. Kant emphasizes pure practical reason (Kant 2008, 31-32) for the moral consideration of the will. The will as faculty to choose ought to be motivated by reason. It is a practical necessity that we act with the good will for the sake of knowledge. Knowledge sharing would be successful if the act is performed with obligation and duty. Action in this mode transcends the personal feeling and desire.

The performance of action is important, because mere good will for caring is not completely free from doubts. Hence, Pradhan (2001) stresses that the recent metaphysics of value should be grounded and exhibited in action. He writes,

Actions are repository of human wishes, desires, motives and intentions. In action alone the whole man is revealed. This is the reason why for understanding the man we have to looking into his behaviour, his character, and above all his inner will (cf., 644-675).

Unless actions are connected with the will, motive and intention of the agent valuing cannot be successfully done. There is a need to develop a comprehensive point of view which would help in judging the person's action as well as the personality. In the pursuit of epistemic activities the integration between action and agent is important for the development of knowledge.

Knowledge sharing as collective activity must be intended together. This togetherness creates an independent locus by virtue of the moral concern human intentionality. It creates a higher marker - status function by showing the attitude of belongingness and cooperation. For Searle,

The capacity for social cooperation is biologically based capacity shared by human and many other species. It is a capacity of collective intentionality is just the phenomenon of shared form of intentionality in human ... exists both in the form of cooperative behaviour and consciously shared attitudes such as shared desires, beliefs, and intentions. Collective intentionality is all that is necessary for the creation of simple form of social reality and social facts (Searle 2007, 84-85).

Collective intentionality shows how every individual shares and participates in collective action. Every person integrates themselves with the other - is an involvement doing something good is a cause in itself to be shared with love shows that social dimension of caring (Searle, 2007, p. 37). This involvement is an indicator of self-less motivation and concern for others as well as for the sake of caring knowledge per se. And this can form a reality - reality constituted by social or collective intentionality. The form of this intentionality is such that it could be independently located - out 'there' (Searle 2007, 87 \& Bratman 1999, 123) and collectively shared. Collective intentionality is not an 
entity is someone's mind; rather it is an act of working collectively for a common goal and intending to create institutional facts. Institutional facts are independent of brute facts and the subjective attitudes of the agents. Though institutional facts are created by individual intentionality it cannot be reduced to a particular intention of an agent. Rather, collective intentionality gives birth a status function of the institution - deontic power to regulate individual behaviors. Thus, many of our social institutions, money, marriage, political power, etc., are formed on this collective intentionality - we intentionality (Searle 1995). It provides an ontological foundation of social reality on which the intentional attitude of mutual reciprocity, commitment and responsibility are based.

\section{Conclusion}

To conclude, the intentionality of knowledge sharing as an obligatory action unifies rationality with normativity for making knowledge and sharing knowledge as intrinsically valuable. Knowledge creation and dissemination is social responsibility. Though knowledge creation has a subjective root, but in the process of articulation it transcends its subjectivity and enters into the realm of the social. In this realm, knowledge is shared, validated, objectified, practiced, and preserved. All these can be accomplished by giving primacy to the normativity of knowledge sharing. Organizations and institutions not only producing knowledge but also working for patents, copy rights and intellectual rights for the regulation of knowledge in the national and international levels. Knowledge construed in such normative framework should aim achieving harmony by involving mutual reciprocity, commitment, and responsibility. On the other hand, knowledge sharing as voluntary action generates fear of reducing the normative condition of sharing to the personal level thereby has scope for asserting its personal ontology. This may also create an apprehension of breaching the harmony that is necessary for the proliferation of knowledge. And thus, further it may act as denial of the moral right to knowledge. The assertion of right to knowledge should involve the good will and obligation to share it with others. That latter becomes a primary concern for the knower because they put a normative demand on him. That is to say, that insists on caring about the caring the knowledge. Thus, the normativity of knowledge sharing goes beyond the psychological and the economical desire by integrating the moral commitment and responsibility into the very process of acquiring knowledge and establishing its relationship with social ontology. 


\section{Literature}

Acharya, N. 1952. Vidya Prasamsa: Subhasita Ratna Bhandara. In Narayana (Ed.), $8^{\text {th }}$ edition. Bombay: Nirnaya Sagar.

Audi, R. 2005. Wrongs within Rights. Philosophical Issues 15, Normativity: 121139.

Audi, R. 2007. Moral Value and Human Diversity. New York: Oxford University Press.

Bratman, M. E. 1999. Faces of Intention: Selected Essays on Intention and Agency. Cambridge: Cambridge University Press.

Chattopadhyaya, D. P. 1991. When Knowing the World Makes Man Happy? In R.K. Mishra \& B. M. Sagar (Eds.), Knowledge, Reality and Happiness. Shimla: Indian Institute of Advance Study.

Dalmiya, V. 2002. Why Should a Knower Care?, Hypatia 17: 34-52.

Dancy, J. 2000. Practical Reality, Oxford: Oxford University Press.

Hyman, J. 1999. How Knowledge Works. The Philosophical Quarterly 49: 433 451.

Kant, I. 1964. Groundwork for the Metaphysics of the Morals, trans. H. J. Patton. New York: Harper Torch Books.

Kant, I. 2008. Groundwork to the Metaphysics of the Morals, trans. T. Kingsmill Abbott. Radford: Wilder Publications.

Searle, J. R. 1970. Speech Acts: An Essay in Philosophy of Language. Cambridge: Cambridge University Press.

Searle, J. R. 1983. Intentionality: An Essay in Philosophy of Mind. Cambridge: Cambridge University Press.

Searle, J. R. 1992. The Rediscovery of the Mind, Massachusetts: The MIT Press.

Searle, J. R. 1994. The Connective Principle and the ontology of the Unconscious: A Reply to Fodor and Lepore. Philosophy and Phenomenological Research 55: 487-855.

Searle, J. R. 1995. The Construction of Social Reality. London: Penguin.

Searle, J. R. 2007. Freedom and Neurobiology: Reflection on Free Will, Language, and Political Power. New York: Columbia University Press.

Schmitz, K.L. 1994. The First Principle of Personal Becoming. The Review of Metaphysics 47: 757-774. 
Sen, A. 1987. On Ethics and Economics. New Delhi: Oxford University Press.

Toumela, R. 1991. We Will Do it: An Analysis of Group Intention. Philosophy and Phenomenological Research 51: 249-277.

Schumacher E. F. 1993. Small Is Beautiful: A Study of Economics As if People Mattered. London: Vintage.

Matusik, S. F. 2002. An Empirical Investigation of Firm: Public and Private Knowledge. Strategic Management Journal 23: 457-467.

Panda, R. K. 1997. Intentionality of Mental Reference (Discussion). Journal of Indian Council of Philosophical Research, Vol. XV: 93-97.

Pradhan, R. C. 2001. Recent Development of Analytic Philosophy. New Delhi: Indian Council of Philosophical Research.

Spencer, J. W. 2000. Knowledge Flows in Global Innovation System: Do U. S. Firms Share more Scientific Knowledge than their Japanese Rivals?, Journal of International Business Studies 31: 521-530.

Stanley, B. \& Stanley, M. 1988. Data Sharing: The Primary Researcher's Perspective. Law and Human Behaviour 12: 173-180.

Visvanathan, S. 2006. Friend and Freud. Outlook.

Werkmeister, W. H. 1967. Man and His Values. Lincoln: University of Nebraska Press. 
Ranjan K. Panda (IIT Bombay, India)

\title{
Ethics of Knowledge Sharing: A Perspecitve of Social Ontology
}

\begin{abstract}
In the contemporary socio-economical scenario, knowledge sharing has become a crucial topic for discussion. As the economy of the societies becoming knowledge centric, knowledge production and dissemination by the educational and other social institutions must play an important role. In this paper, we discuss the notion of knowledge sharing as normative action involving two modes of function: voluntary and obligatory. Knowledge sharing as voluntary action presupposes personal ontology of knowledge. The knower as owner of knowledge has the right to disseminate knowledge. The reason of this dissemination could be sometimes to fulfill certain psychological desire or material needs, rather than purely value centric. Such a mode of sharing could be the reason for the degeneration of knowledge. It is because voluntary dissemination of knowledge does not go beyond the whims and fancies of the knower. On the other hand, knowledge sharing as an obligatory action emphasizes care and commitment. These normative elements could not only transform the attitude of the knower, but also help him to transcend the mere economic and psychological reasons of knowledge sharing. This transcendental logic of sharing would show how knowledge obtains its social ontology.
\end{abstract}

Keywords. Ethics, knowledge sharing, knowledge production, intentionality, normativity, collective intentionality, cultural background, Obligatory action, care and commitment, institutional facts, moral responsibility, social ontology.

Citations. Reference this paper as: Panda, R. K. (2012). Ethics of Knowledge Sharing: A Perspective of Social Ontology. Ethics in Progress Quarterly, Volume 3, Issue 1, pp. 53-70, available online at ethicsinprogress.org. 